\title{
Improve Learning With Moving Images
}

\author{
Muh. Yazid ${ }^{1 *}$, Lale Aprihatin Diana Safitri², Rifa'atul Mahmudah ${ }^{3}$ \\ ${ }^{1}$ Primary Education, Universitas Hamzanwadi, Lombok Timur, Indonesia, \\ ${ }^{2}$ IAIQH Bagu, Lombok Tengah, Indonesia \\ ${ }^{3}$ Primary Education, Universitas Hamzanwadi, Lombok Timur, Indonesia, \\ *Corresponding author. Email: mh.azzaidan16@gmail.com
}

\begin{abstract}
This study aims to determine how many students learning increases in Primary Education. This research is classified as experimental research because in this study the researcher wanted to see the use of moving images in improving student learning. The study population was all students of Primary Education. The sample of this research is class V Primary Education. Data collection techniques in research is a test, which is used in the form of a written test in the form of pre-test and post-test to determine the ability of students to master the material that has been studied before and after treatment (treatment). The results of the study can be seen from the average value of the control class pre-test which is 54.25 while the average value of the experimental class pre-test is 63 so it is worth comparing because the difference is not significant. After learning is finished then post-test is done, both in the control class and the experimental class. The average post-test score of the control class is 64.5 while the average post-test value of the experimental class is 82 . The increase in the average value of pre-test to post-test in the control class was $18.35 \%$, while the increase in the average value of the pre-test to post-test in the experimental class was $25.10 \%$. An increase in the average value of both the control class and experimental class. But the increase in the average value that occurs is greater in the experimental class than in the control class. So it can be concluded that learning with moving images aided by Microsoft PowerPoint enhances learning.
\end{abstract}

Keywords: Learning, images, moving images

\section{INTRODUCTION}

These guidelines, the development of the current era more or less gives color to the world of education, both from the curriculum that governs the course of education to teaching which is the benchmark for success or failure of education. The presence of technology in education cannot be underestimated. Technology provides an important role in the education or learning of students in schools. Technology or learning media specifically designed for students that are appropriate to students' development and age will contribute to the pursuit of learning of students at school or madrasah.

Students with all the characters they have both from hearing and vision and learning styles will require a variety of media (C.-M. Chen \& Wu, 2015). Teachers in this case as the spearhead of learning must be selective in choosing and using media in students. The teacher must consider and must know how to use media in students (Krutka \& Carpenter, 2016). Use media to all students without differentiating them. The technology or media used in student learning must vary given the development of learners that vary from low media, medium media, and high-level media (Kaplan \& Haenlein, 2016).
The low media are media or technology that does not require electrical connections, do not need a connection (plugs), do not also use a battery like a magnifying glass used to magnify the size of writing to help students who are slightly disturbed in vision (Martinez et al., 2016). Middle technology or media is a medium that requires electrical voltage which is used to help student learning (Comer, 2015). While technology or high-level media is a medium that involves electrical voltage or depends on the whole media such as computer devices, LCDs and others.

The use of media in learning will provide experiences to students in learning. Learning is the development of new knowledge, skills, or attitudes when a person or student interacts with the environment. Student involvement in learning includes physical, emotional, and media involvement. The media used in the learning process is moving media aided by Microsoft powerpoint.

The use of instructional media especially in learning enables effective educational interactions between teachers and students, and between students and students as well as between students and the media and the surrounding environment (McGrew et al., 2017). This can affect the learning process to be more effective in all learning activities. With the use of media images of 
students or students can learn more actively. Student learning activities will depend on the varied learning methods used by the teacher. By applying the appropriate learning methods the researchers feel there will be a cooperative relationship, communication, and interaction between students (Smith, 2015). The goal is that students can learn actively in-class learning.

The development of science and technology is increasingly encouraging renewal efforts in the use of technological outcomes in the learning process. The teachers are required to be able to use the tools that can be provided by the school, and it is also possible that the tools are following student development (Albion et al., 2015). The teacher can at least use inexpensive and efficient tools that, although simple and simple, are imperative in the effort to achieve the expected teaching objectives. Besides being able to use the available tools, the teacher is also required to be able to develop skills in making instructional media that will be used in the media is not yet available. For this reason, teachers must have sufficient knowledge and understanding of learning media.

The situation in the field is the seriousness of students in learning because the teacher teaches in a conventional way or by explaining the material to students in front of the class. This is what makes students bored with learning. This situation occurred in Primary Education.

Teachers can design learning that is more interesting than just lectures, through this PowerPoint software the teacher provides learning experiences for students especially elementary school students who are practically lay in computer equipment (Savery, 2015). This PowerPoint program has simple icon displays that are easy to use. Teachers also do not have to learn the term language in computers or programming because this program is already available in the Microsoft Office package. The advantage of moving pictures is their concrete nature, through pictures students can see something that is being talked about or discussed in class. Some problems can be explained with pictures other than words. Another advantage of this software besides being able to enter text and images, we can also insert sound files and video files that are very supportive in-class learning (Robin, 2016).

The use of Microsoft power points in learning adds to the excitement of students in Learning. This is because students are not monotonous in listening to the teacher in explaining the material in front of the class. Microsoft Powerpoint is a computer program that is a Microsoft product software that is developed and enabled for making slides to facilitate teachers in presentations that have several tools to help design slides so that they appear more attractive and easier to control during presentations (Sumantri \& Rachmadtullah, 2016).

The program consists of several visual elements and operational control. The visual element in question, consisting of slides, text, images, and areas of color can be combined with backgrounds that have been available in Microsoft PowerPoint applications. We can make such visual elements immobile or move according to our wishes or according to the learning needs that we carry out in class. All views of this Microsoft powerpoint program can be adjusted according to learning needs, whether it will run by itself according to the desired time or run manually using an existing mouse or cursor (Tanenbaum \& Bos, 2015). Usually when used for the delivery of teaching materials that are concerned with the occurrence of interaction between students and teachers or teachers, then control the operation using the manual method.

Students lack learning experience if in learning the dominant teacher uses the lecture method. To overcome this, the teacher needs learning media that can attract students 'interests and reduce students' boredom in learning. Therefore we need a computer-aided media with the form of text, visual and animation so that it can help students gain more knowledge, understand deeper concepts, and know the applications being studied (H.-R. Chen et al., 2015). The computer-assisted learning media can use PowerPoint Presentation software.

Learning is an activity carried out to initiate, facilitate and increase the intensity and quality of learning in students. Learning can't be separated from the process and learning outcomes. Learning must be intentionally organized well to foster a good learning process which in turn can achieve optimal learning outcomes (Paolini, 2015).

The situation in the field is the seriousness of students in learning because the teacher teaches in a conventional way or by explaining the material to students in front of the class. This is what makes students bored with learning. This situation occurred in Primary Education.

Research results revealed that the high learning outcomes of learning applied in this study were due to the students who were taught using powerpoint learning media more passionate in accepting lessons because teaching material was delivered in the form of power points accompanied by animations that we're able to direct to an object so that it looks alive or give a moving picture to something static (Clarke \& Mcphie, 2016). To be able to usher in an abstract student imagination into something real.

Teachers can design learning that is more interesting than just lectures, through this PowerPoint software the teacher provides learning experiences for students especially elementary school students who practically lay in computer equipment (Wanner, 2015). This PowerPoint program has simple icon displays that are easy to use. Teachers also do not have to learn the term language in computers or programming because this program is already available in the Microsoft Office package (Bell et al., 2017). The advantage of moving pictures is their concrete nature, through pictures students can see something that is being talked about or 
discussed in class. Some problems can be explained with pictures other than words. Another advantage of this software besides being able to enter text and images, we can also insert sound files and video files that are very supportive in-class learning.

\section{METHOD}

In the Method section, this research is classified as experimental research because in this study the researcher wanted to see the use of moving images in improving student learning. This research uses the help of Microsoft PowerPoint.

1.1. Population and sample

The study population was all students of Primary Education in the odd semester of the 2019-2020 school year. The sample of this study was fifth-grade students of Primary Education in the odd semester.

\subsection{Time and Place}

This research was carried out in the second semester know 2018-2019 lessons in Primary Education

\subsection{Data collection technique}

\section{The following are the data collection techniques in this study:}

Observation / Observation: This observation is used to obtain data about the state of students at school and the process of teaching and learning activities in the classroom and school environment (Karatas \& Baki, 2017). In the observation phase of teaching and learning activities carried out things as follows: 1) Observing learning activities using powerpoint media; 2) Observing the situation when students learn to use media powerpoint; 3) Observing obstacles and things that make it easier for students to learn.

Interview: To complete the required data, researchers conducted interviews with Primary Education teachers regarding learning techniques, allocation of learning time, and evaluation of learning.

Test: The test used in the form of a written test in the form of a pre-test and post-test to determine the ability of students to master the material that has been studied before and after treatment (treatment). This test is carried out in the control group and the experimental group.

Documentation: Documentation is used to obtain data about the organizational structure, the teacher's condition, the situation of students in the school and other documentation that can be used for completeness of the data.

\section{Data Analysis}

After the data is proven to be normal and homogeneous distribution, the next step is to analyze the data. To analyze and interpret the data obtained from the sample used to determine differences and increase in value (Sall et al., 2017; Zanoni et al., 2016). Qualitative analysis is also used in this study as support in describing the facts obtained from research results. The technique used in this qualitative analysis is an inductive technique derived from special facts and concrete events. Then from these facts, general conclusions are drawn.

\section{RESULTS AND DISCUSSION}

\subsection{General description of moving image}

Applicative learning media are needed to facilitate the teaching and learning process, such as learning media in Primary Education. Learning media, in this case, Microsoft PowerPoint, is intended as a learning aid, in the form of software. This learning media is intended to facilitate students in learning and understanding the material taught by the teacher. The material taught by using Microsoft PowerPoint is material adapted to the material in the syllabus, and learning media is developed and adapted to the development of students in Primary Education

\subsection{Implementation of Microsoft PowerPoint Experiment Class Control (Primary Education)}

The control class is a class that is not taught using learning media or Microsoft powerpoint media. In this case, the chosen group to be the control group is class $\mathrm{V}$ Primary Education. This class is taught by the method commonly used by the teacher. The method used in this class is lecturing. The media used are the blackboard and the White Board as well as other learning tools. Learning activities, namely, before the lesson begins, students are given a pretest question to determine the initial state of students. Then after the pretest is finished, continue with the lesson as usual with the lecture method. After the course material is delivered, students are given a posttest to find out the level of student understanding. The results of the pretest and posttest control class students are presented in the following table. The comparison table of the pretest and posttest scores of the control class is presented in the table below. Primary education

Table 1. Class Control

\begin{tabular}{lll}
\hline Value & Pre-test & Post-test \\
\hline Highest & 61.5 & 68.5 \\
The lowest & 47 & 60.5 \\
Average & 54.25 & 64.5 \\
\hline
\end{tabular}

The data above is taken from the learning outcomes in the control class and there is a difference in the score or increase in the pretest and posttest of $18.35 \%$

\subsection{Implementation of Microsoft PowerPoint Experimental Class (Primary Education)}


Experimental class is a class that is taught using learning media with Microsoft power points that have moving images in them. In this case, selected to be the experimental class is class $\mathrm{V}$. This class is taught using lecture and demonstration methods. The media used are blackboards, laptops, LCD projectors, and textbooks. The learning activities are before the material is given, students are given a pretest question. After the pretest is finished, students are given material using media that has been created with the help of Microsoft powerpoint. Posttest questions are given after the material has been submitted to determine the level of student understanding of the material being taught. The pretest and posttest scores of the experimental class students are presented in the table in the appendix. The comparison table of the pretest and posttest scores of the experimental class is presented in the following table.

The comparison table of the pretest and posttest scores of the experimental class is presented in the table below:

Table 2. Experiment Class

\begin{tabular}{lll}
\hline Value & Pretest & Posttest \\
\hline Highest & 76 & 94 \\
The lowest & 50 & 70 \\
Average & 63 & 82
\end{tabular}

The data above is taken from the learning outcomes in the experimental class and there is a difference in the value or increase of the pretest and posttest by $25.10 \%$

\section{DISCUSSION}

Learning is done with Microsoft PowerPoint is done with an experimental model, which compares the learning of control class students and the experimental class. Learning in the control class is done by lecture, question and answer, and discussion methods. The learning media used are blackboards and material packages. Learning in the experimental class is the same as learning in the control class, but the main media used is the viewer to display media that are assisted by Microsoft PowerPoint development results, while the blackboard as supporting media. The pretest and posttest questions are given to the control class and the experimental class is also the same (the parameters are the same).

This is done to be able to measure differences in student learning between classes that use Microsoft PowerPoint learning media and classes that do not use Microsoft PowerPoint learning media. The average value of the pretest of the control class is 54.25 while the average value of the pretest of the experimental class is 63 the difference is not significant. After learning is finished then posttest is done, both in the control class and the experimental class. The average value of the control class posttest is 64.5 while the average value of the experimental class posttest is 82 . The increase in the average value of the pretest to posttest in the control class is $20.35 \%$, while the average increase in the value of the pretest to posttest in the experimental class by $25.10 \%$. An increase in the average value of both the control class and experimental class. But the increase in the average value that occurs is greater in the experimental class than in the control class. So it can be concluded that learning with moving images aided by Microsoft PowerPoint enhances student learning.

\section{CONCLUSIONS}

Based on the results of research and discussion, conclusions can be drawn that: 1) The learning process with moving images aided by Microsoft PowerPoint goes through several stages, namely from the identification of problems and potentials to making presentations with Microsoft power points; 2) The use of moving images with rocky Microsoft PowerPoint is very feasible to use to support learning in the classroom because it also increases learning outcomes and also increases student enthusiasm for learning es

pecially in elementary schools; 3) The application of learning media has been carried out with the experimental method, which is comparing student learning outcomes in groups that do not use learning media with Microsoft PowerPoint. The result is a difference in the average value, namely for the control class an average value of 64.5 while for the experimental class of 82 so that the learning media with Microsoft PowerPoint is effective for improving student learning.

\section{ACKNOWLEDGMENTS}

Thank you to all parties (which we cannot mention one by one) for their assistance in completing this research. Hopefully what becomes the help of ladies and gentlemen becomes a charity that multiplies its value.

\section{REFERENCES}

Albion, P. R., Tondeur, J., Forkosh-Baruch, A., \& Peeraer, J. (2015). Teachers' professional development for ICT integration: Towards a reciprocal relationship between research and practice. Education and Information Technologies, 20(4), 655-673.

Bell, T., Duncan, C., \& Rainer, A. (2017). What is coding? In Creating the Coding Generation in Primary Schools (pp. 3-21). Routledge.

Chen, C.-M., \& Wu, C.-H. (2015). Effects of different video lecture types on sustained attention, emotion, cognitive load, and learning performance. Computers \& Education, 80, 108-121.

Chen, H.-R., Liao, K.-C., \& Chang, J.-J. (2015). Design of digital game-based learning system for elementary mathematics problem solving. 2015 8th International Conference on Ubi-Media 
Computing (UMEDIA), 303-307.

Clarke, D. A. G., \& Mcphie, J. (2016). From places to paths: Learning for Sustainability, teacher education and a philosophy of becoming. Environmental Education Research, 22(7), 10021024.

Comer, D. (2015). Computer networks and internets. Pearson.

Kaplan, A. M., \& Haenlein, M. (2016). Higher education and the digital revolution: About MOOCs, SPOCs, social media, and the Cookie Monster. Business Horizons, 59(4), 441-450.

Karatas, I., \& Baki, A. (2017). The effect of learning environments based on problem solving on students' achievements of problem solving. International Electronic Journal of Elementary Education, 5(3), 249-268.

Krutka, D. G., \& Carpenter, J. P. (2016). Why social media must have a place in schools. Kappa Delta Pi Record, 52(1), 6-10.

Martinez, C. M., Hu, X., Cao, D., Velenis, E., Gao, B., \& Wellers, M. (2016). Energy management in plug-in hybrid electric vehicles: Recent progress and a connected vehicles perspective. IEEE Transactions on Vehicular Technology, 66(6), 4534-4549.

McGrew, S., Ortega, T., Breakstone, J., \& Wineburg, S. (2017). The Challenge That's Bigger than Fake News: Civic Reasoning in a Social Media Environment. American Educator, 41(3), 4.

Paolini, A. (2015). Enhancing Teaching Effectiveness and Student Learning Outcomes. Journal of Effective Teaching, 15(1), 20-33.

Robin, B. (2016). The power of digital storytelling to support teaching and learning. Digital Education Review, 30, 17-29.

Sall, J., Stephens, M. L., Lehman, A., \& Loring, S. (2017). JMP start statistics: a guide to statistics and data analysis using JMP. Sas Institute.

Savery, J. R. (2015). Overview of problem-based learning: Definitions and distinctions. Essential Readings in Problem-Based Learning: Exploring and Extending the Legacy of Howard S. Barrows, 9, 5-15.

Smith, J. A. (2015). Qualitative psychology: A practical guide to research methods. Sage.

Sumantri, M. S., \& Rachmadtullah, R. (2016). The effect of learning media and self regulation to elementary students' history learning outcome. Advanced Science Letters, 22(12), 4104-4108.

Tanenbaum, A. S., \& Bos, H. (2015). Modern operating systems. Pearson.

Wanner, T. (2015). Enhancing Student Engagement and Active Learning through Just-in-Time Teaching and the Use of Powerpoint. International Journal of Teaching and Learning in Higher Education, 27(1), 154-163.

Zanoni, M., Piccinini, F., Arienti, C., Zamagni, A., Santi,
S., Polico, R., Bevilacqua, A., \& Tesei, A. (2016). 3D tumor spheroid models for in vitro therapeutic screening: a systematic approach to enhance the biological relevance of data obtained. Scientific Reports, 6(1), 1-11. 